\title{
EDUCATIONAL JOURNALISM IN UKRAINE (RESULTS OF CONTENT ANALYSIS)
}

\author{
Petro Katerynych \\ Taras Shevchenko National University of Kyiv \\ vul. Yuria Ilyenka, 36/1, Kyiv, 04119, Ukraine \\ (D) https://orcid.org/0000-0002-5967-2368 \\ katerinich1993@gmail.com
}

\begin{abstract}
The article describes theoretical approaches to understanding educational journalism, characterizes the concepts of educational journalism in the Ukrainian and global media space, and builds a model of influence of external factors on the coverage of education issues in the mass media outlets. The tasks of the research are: 1) to study theoretical developments and approaches to the functioning of educational journalism in the media environment; 2) to trace the genre and thematic features of the analyzed educational media outlets (on the example of "Pedpresa", "Osvita.ua", "New Ukrainian School", "Osvitoria"). The research methodology is content analysis of specialized media on educational topics. These media have a regular infill of multigenre and multithematic content of educational topics, actively use tools to create a multimedia content, have a high traffic in the segment of online media educational profile (according to the service statistics "Similar Web"). It was found among the analyzed content of the four online media of educational specialization $(3,352$ publications $)$ that by the genre structure notes prevail $(2,714 ; 80.9 \%)$, there is a lack of reportage $(56 ; 1.7 \%)$ and interviews $(130 ; 3.9 \%)$. The low number of analytical genres is especially noticeable with regard to the topics of preschool, inclusive and vocational education. A content analysis in Group 1 (2,366 materials, $70.6 \%$ of the total sample in the two groups) showed that the largest number of materials during the analyzed period concerned the topics of primary and secondary education $(1,131$ materials, $47.8 \%)$, and the smallest number concerned vocational education $(131,5.5 \%)$. Analysis of materials in the Group 2 (29.4\% of the materials considered in both groups) showed that the topic of primary education prevails (401 materials, 40.7\%), the share of materials relating to distance education is significant (16.7\% in "NUS" and 16.9\% in "Osvitoria"). Most of the materials of the media "PedPresa" (83\%), as well as a significant part of "Osvita.ua" (63\%) are borrowed or supplemented by the material from the sites of the MESU, UCEQA or other sources. These results determine the practical value of the study.

Keywords: educational journalism; education journalist; mass media outlets; content analysis; educational journalism in Ukraine.
\end{abstract}

\section{Introduction}

Looksmi's media monitoring data "The state of the Ukrainian education system in 2016" demonstrates that "the educational topic is covered less than other current government ones", there is a "shortage of analytical materials", "no advertising and communication campaigns" in the education field. The number of materials about science does not exceed $1 \%$. "There are almost no materials related to vocational education" (CS MESU, 2017-2019).

The research objective is to comprehensively study the current state of educational journalism in Ukraine and its development prospects, based on Ukrainian and international experience and analysis of selected publications.

The objectives of the work correspond to the set tasks:

1. To study theoretical developments and approaches to the functioning of educational journalism in the media environment,

2 . To trace the genre and thematic features of the analyzed educational media outlets (on the example of specialized online media outlets such as "Pedpresa”, “Osvita.ua”, "New Ukrainian School", “Osvitoria”).

Meanwhile, there are a number of theoretical and practical problems, including:

- Lack of analytical and poor quality of author's content on education in the analyzed specialized publications, as well as absence of balance while covering various fields of education distort the content of educational journalism and requires the transformation of the genre content of Ukrainian educational media outlets.

- A related problem is the weak presence of the analyzed media outlets in the media quintet (desktop version, mobile version, mobile application, tablet version, adaption for use in smartwatches), which is a necessary component of the digital evolution of modern online media outlets for greater involvement and expansion of audience. (García, 2014).

\section{Literature review}

First of all, educational journalism is the production and dissemination of current news, which are 
interesting to the educational audience. Educational audience is a very broad definition. It includes all those involved in different levels of education, as well as the educational process (children - parents teachers - experts). Educational journalism is sometimes considered in the context of the "lifelong education" concept proposed by UNESCO (Institute for lifelong learning). Continuous education begins from birth and ends with death. That is why "lifelong learning" is the subject of discussion among education experts, since education is compared to the form of existence, accompanying the person of the 21st century every day and becomes the main philosophy of "learning society" (Wain, 2016). In Ukraine, the philosophy of "lifelong learning" is not yet systematically developed" (Karpenko, 2015).

The "knowledge society" puts knowledge next to labor, capital and nature. The processes of production of material goods become less important than information processes based on knowledge. The knowledge economy changes the traditional relations between "employee and employer" (Kefela, 2010 , p. 60). This is reflected in the increase in the number of professions that require higher education and encourages us to emphasize the social role of journalists as facilitators of educational communication, involved in the process of rational understanding of processes in the "knowledge society".

The main ideas of the concept of "knowledge society" were set out and summarized in the UNESCO World Report "Towards knowledge societies". The document states that "the knowledge society differs from the information society because the latter is based on the concept of technology, while the former has broader social, ethical and political parameters" (Petrushenko, 2016, p. 106).

Spanish researcher G.Pérez writes:

In addition to sectoral or thematic specialization of research and professional practice, educational journalism is a systematic reflection of educational aspects and current information in the educational space, a necessary complement to modern education and is crucial for social orientation, which we call "educational society" or "lifelong learning." (Pérez, 1998)

Immanent factors of educational journalism are child-centered, human communication, the ability to present information on educational topics in a nonstandard way, build a dialogue between areas of interest without the use of clerical words and operating various formats and tools of message formation (Katerynych, 2020, p. 153). That is the reason why communication moves to the stage of "real stories", through which information is given in a more accessible manner and creates interaction between the communicator and recipient. It is important to understand that creating content on educational topics requires specialists who are able to present information in an orderly and accessible manner, trained in genre features, able to work with multimedia tools, involving experts and mind leaders (Dryzytska, 2019). Regarding the work with educational content, educational content creators and educational newsmakers should be distinguished.

Anybody can be an educational content creator a teacher, student, student's father, blogger, etc. An educational content creator produces educational material that meets the interests and objectives of the target audience. Such content can have a variety of forms, including blog notes, videos, e-books, photos, and infographics. A content creator is an author, researcher, industry expert, editor, who has the ability to work with multimedia tools and social networks (Cohen, 2012).

A newsmaker is a public figure or organization. Newsmakers are educational politicians, reputed educators (rectors, principals) or just people who find themselves in unusual circumstances or witness events that become the background for the news. Public figures often become newsmakers by taking concrete action (for example, they try to solve an external independent evaluation task or attend classes at the New Ukrainian School). Reputation, competence, independence, inside information all characterize a suitable newsmaker (YourDictionary. Newsmaker). Example: Facebook group "SOS Parents".

An education journalist primarily works with a significant amount of information - most social progress leads to changes in the educational process, in addition, each new team of the executive tries to make changes and implement reforms (Lemos, 2017). An education journalist should have several key skills - not just the ability to work with multimedia tools, but also a multimedia mind (The Multimedia Mind-Set), which can analyze information and draw conclusions (Wenger\&Potter, 2007). I. Zhylavska notes:

In the process of interaction between a journalist and the youth, a journalist may have different attitudes, including manipulative strategies that rise above the audience, giving the journalist the "right" to consider their readers as an object of management (education, formation of certain abilities in them), while considering himself as a carrier or translator of management programs of different types and levels. Instead, the second attitude places the journalist next to the audience and orients her or him to the relationship of information, the third fundamental attitude requires the journalist to be within a certain human community, considering herself or himself as an interested participant in the joint search for solutions to certain problems. (Zhilavskaja, 2008, p. 13)

The last model of interaction is especially interesting for our research.

Researcher Darlene Opfer writes on the impact of journalism on education: "The belief that the media 
outlets have contributed to civil disunity in the literal sense of the word and, in particular, to the decline in public support is so widespread among researchers that it seems an indisputable fact." (Opfer, 2007, p.166). Opfer notes that, according to many researchers, the general ignorance of the state of affairs in education is provoked by the "media people". "There is an opinion that the society's exclusion from state institutions and ignorance in such public issues as education is a matter of the media," Opfer says. As the researcher notes, "Some scholars have focused on structural causes, such as economic pressure on the news industry, which has led to erosion of standards and reduced public service orientation" (Killeen, 2007), (Moses, 2007), (Wallace, 2007). Other researchers paid urgent attention to cultural approaches that attributed the negative impact of the media on education by the growing hostility of the news culture (Anderson, 2007), (Haas, 2007).

However, Opfer believes that the abovementioned studies have three fundamental shortcomings: a) they are not systematic and reflect the historical view of the impact on the mass media outlets, which depends significantly on the context; b) the attributes are conditioned by incorrectly in- terpreted correlations; and (c) researches are based on the incorrect assumptions about the role of the public as information consumers (Opfer, 2007, p. 166).

Some scholars, in particular those who support the theory of standard erosion, focus on changes in policy in general. They state that the media coverage of education is insufficient and of poor quality, because the number of consultants, experts and campaigns related to specific education issues has increased. Additionally, scientists point out the ideological polarization (see Haas, 2007, Killeen, 2007, Wallace 2007). Other researchers explain the decline in media attention to education by the growing number of television shows, as well as the development of popular music, advertising, and the film industry (Tillman\&Trier, 2007). These different approaches are united by the belief that the public's exclusion from education and distrust of it is caused by the insufficient or poor coverage of education issues in mass media outlets. According to the abovementioned theories, it is possible to build a model of the influence of external factors on the low coverage of education by the mass media outlets (Figure 1).

Figure 1: Model of influence of external factors on the coverage of education issues in the mass media outlets

THE MODEL OF

INFLUENCE ON THE COVERAGE OF EDUCATION IN THE MASS MEDIA OUTLETS BY EXTERNAL FACTORS

The intersecting circles mean

the substitution of various

factors influencing media

coverage of education

Source: study of

scientific publications of Opfer (2007),

Killeen (2007), Moses (2007), Wallace

(2007), Haas (2007), Tillman \& Trier

(2007).

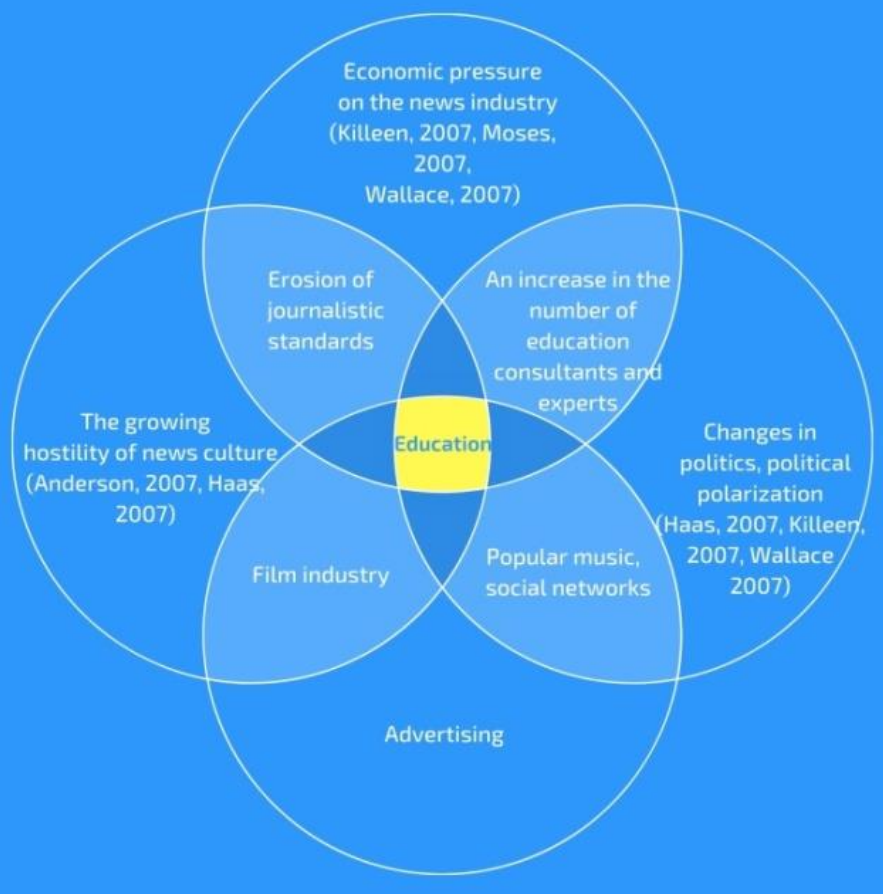

Source: study of scientific publications of Opfer (2007), Killeen (2007),

Moses (2007), Wallace (2007), Haas (2007), Tillman \& Trier (2007). 
The researchers simultaneously note the intersection of the goals of the "educational society" with the "participative democracy". Educational society is characterized by socio-centered, culture-centered, human-centered and knowledge-centered approaches (Subetto, 2013, p. 5).

John Dewey wrote that education "cannot be limited by the teacher and function without a social environment" (Hansen, 2002). "Therefore, mass media outlets are one of such powerful forces in the social environment of education. With the help of modern electronic methods and technologies, mass media outlets prove that education is really comprehensive, not limited to the four walls of the classroom" (Preeti, 2014, p. 174).

It is noteworthy that educational media outlets are not media killers or media terrorists; they less often cause public response than multidisciplinary or news media outlets (Nacos, 2016). However, they perform important functions, namely "informing, cognitive, critical, stratification, scientific-innovative, debunking myths, evaluative-stimulating and entertaining" (Katerynych, 2020, pp. 155-156).

Sensationalism in educational journalism is not a "higher order" value. The rule "if it bleeds, it leads" does not apply here (Miller\&Albert, 2015, p. 61). However, educational media is also no stranger to the theme of "seven guidelines" - "Scandals, Sensations, Fear, Death, Sex, Laughter and Money" (Detector Media, 2008). Examples of such materials relate to sexual education, corruption, and lifehacks for educational institutions - where to take investments for educational projects; and infotainment materials that use entertainment by informing.

\section{Methodology}

Among the specialized electronic media on educational topics in Ukraine "New Ukrainian School", "Osvita.ua", "Pedpresa", "Osvitoria" should be noted. We choose these media outlets for research because they:

1. Have a regular filling with educational content of various genres and topics,

2. Actively use the tools to create multimedia content,

3. Have the highest traffic in the segment of online media of educational profile (according to the statistics service "Similar Web",

4. Have the most representative structure of educational content in relation to the fields of education.

According to our analysis, carried out using the tools of the Internet traffic research platform "SimilarWeb" for a period of three months (June - August 2019) it was found that the number of visitors to the site "Osvita.ua" was 21.31 million people, "Pedpresa" - 886 thousand people, "Osvitoria" 197 thousand, "NUS" -258 thousand.

According to the research Gemius Audience, 18+ Ukrainian statistics all the resources we analyzed are among the 10 sites that teachers visit most often. In addition, $70.76 \%$ of parents surveyed also get information about educational topics from these sources $(* 30-45,50 \mathrm{~K}+$, families with children under 16, MMl Ukraine, 2018/1-2018/2, all people) (CS MESU, 2019-2021).

During 30.08.2019-30.08.2020 we conducted a quantitative content analysis of the sites of educational online publications "Pedpresa" and "Osvita.ua" (group 1), during 01.02.2020-30.08.2020 - "Osvitoria", "NUS" (group 2) (Internet addresses https://pedpresa.ua/, https://osvita.ua/; https://osvitoria.media/, https://nus.org.ua/). Such chronological frames satisfy our need for analysis of various genres and thematic materials, take into account all the "hot" periods of the educational process - the organization of the educational process (distance learning) and the introductory campaign under quarantine conditions, change the leadership of the Ministry of Education, and identify topics which analyzed media pay more attention to, as well as a range of topics that are "deprived" of such attention. Since the media of group 1 ("Osvita.ua", "Pedpresa") specialize in a wide range of educational topics, the chronos of analysis is chosen wider. For group 2 ("NUS", "Osvitoria") a narrower period of time is enough to understand trends, thematic and genre correlations, as these media outlets specialize only in the fields of primary and secondary education. The study aims at analyzing the content of the following online media sites: "Osvita.ua", "Pedpresa" (group 1), "NUS", "Osvitoria" (group 2) with the content of different topics and different genres for selected periods of analysis.

Internet media outlets have been studied using monitoring methods and elements of the method of quantitative content analysis. For the monitoring representativeness, we were investigating resources on a daily basis during the study period (SP) according to the number of news, genre structure (notes, reports, interviews, articles) and sources of origin of materials (author's material, material based on government source, material based on a certain source governmental, non-governmental (analytical organization or international source), other media, so we can talk about filling online publications with different types of content and get the following vision:

1) quantitative idea of materials on educational topics in the most popular online media outlets on educational topics in Ukraine,

2) thematic content (which topics predominate and were covered the most during the analyzed period),

3) source of materials,

4) regularity of filling with educational content.

Therefore, for the relevance of the study, we do not compare all four media outlets by the same criteria. The same criteria are used to compare "Osvita.ua" and "Pedpresa" (group 1), "NUS" and "Osvitoria" (group 2). The number of analyzed materials $(\mathrm{n}=2366$ in group 1 and $\mathrm{n}=986$ in group 2$)$ allows us to draw conclusions about the presence of different educational topics in the media space and to compare the data obtained in individual groups. 
The general set of the study consists of textual works published on the sites "Osvita.ua", "Pedpresa" (group 1), "Osvitoria" and "NUS" (group 2) in all sections during the study period (group 1 - from 30.08.2019 to 30.08.2020; group 2 - from 01.02.2020 to 30.08 .2020 ). By textual works we mean informational and analytical journalistic materials. The comparison was made by the following categories for group 1 - "preschool education", "secondary education", "vocational education", "higher education", "external evaluation"; for group 2 "primary education" (except for inclusion and funding), "inclusion", "education funding" (allocation of funds, budget, investments, subventions, etc.), "distance education" and "foreign experience". Accordingly, this data constitutes a sample of the study. The correctness of the sample is achieved thanks to the same structure of the original and analyzed populations for both groups.

Analysis units were all text holes published on the sites "Osvita.ua", "Pedpresa", "Osvitoria" and "NUS" during the SP in the relevant sections according to the analyzed groups. The data collected during the SP was entered into a single table in .xls format according to the following procedure:

- date of observation;

- the number of identified analysis units according to each category of analysis (that is the number of textual works of each category published on the sites "Osvita.ua", "Pedpresa", "Osvitoria" and "NUS" on a particular day in a particular section).

Five criteria should be added to the quantitative analysis of media content that, in our opinion, are important for modern media. This is, in particular, "paywall" (paid access to content), which is associated with the market position of the publication (Sjøvaag, 2016, p. 304) and is interesting for the market of educational media in terms of access to unique content for subscribers.

The category of "native advertising" is also introduced into the analysis for the SP, which has already become a "marketing reality" (Manic, 2015, p. 53), "newsletter" (newsletter to e-mails of users of general information collections prepared by the editorial office, or news according to separate headings) and "mobile first" ("mobile platforms first") - whether there are mobile media applications, whether a mobile version with compact navigation is developed, as well as a version for the tablet.

We have also added to the SP a criteria for the amount of information regarding COVID-19, as this indicator is important to us and continues to play a significant role in the organization of the educational process. In order to relevantly calculate the content of materials for COVID-19, we, starting from February 1, 2020 (for both groups), in the process of quantitative content analysis, tracked the amount of materials containing any information about COVID-19 and related it to the educational process in the conditions of threat, quarantine zones, and others. It should be noted that the first case of COVID-19 in Ukraine was recorded in March 2020, but the world has already talked about the possible consequences of a pandemic for education (Ukrainian Truth, 2020), (MESU, 2020).

Additionally, in the process of quantitative content analysis, we determined the sources of each analyzed material - whether it is an author's one, created by the media, or borrowed from official or other sources.

\section{Results of content analysis}

\section{1. "Osvita.ua"}

In the process of quantitative content analysis, we analyzed 1605 materials of various genres on the website of educational media "Osvita.ua" for the period from August 30, 2019 to August 30, 2020. Among them 1362 (84.9\%) were notes, 168 $(10.5 \%)$ were articles, $16(0.9 \%)$ were reports, and $59(3.7 \%)$ were interviews. Both author's and materials linking to official sources (MESU, UCEQA, other sites) were taken into account. Most materials were related to "primary and secondary education" (33.3\%), "higher education" (28.9\%), the least — "science" (8.7\%) and adult education "andropedagogy" (1.8\%).The data on the rubrication and genre structure of the analyzed materials is given below (Figure 2).

Figure 2: The amount of materials in the "Osvita.ua" for the SP in accordance with the analyzed fields of education.

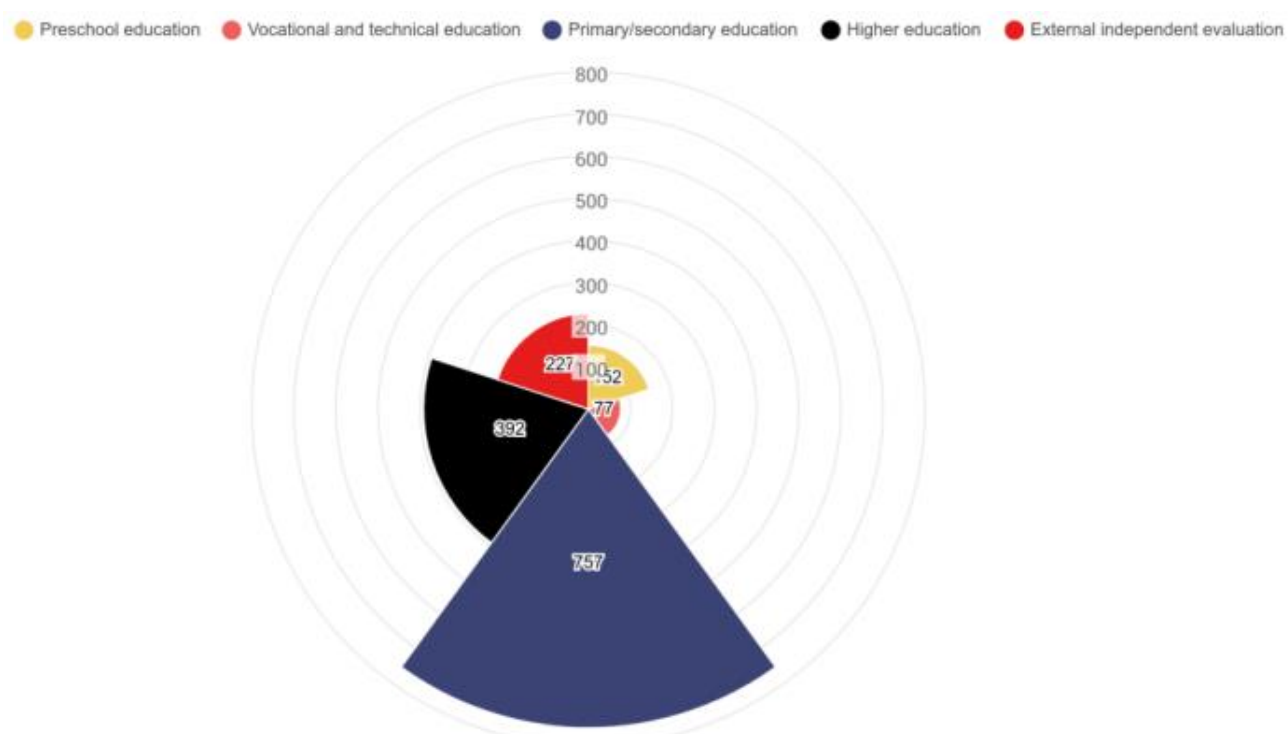

Source: content analysis data for the SP. 
During the analyzed period, inconveniences in using the mobile version of the site were found, it is largely unsuitable for use. Adaptive design and automated content technologies improve navigation if the user is familiar with the desktop version of the site. However, the mobile version does not differ from the desktop one in structure and functionality, which sometimes causes difficulties in finding relevant content using a mobile device. The media quintet (desktop version, mobile version, mobile application, tablet version, adaptation for use in smartwatches) of "Osvita.ua" is of poor quality (see about media quintet García, 2014).

Among the researched content of "Osvita.ua", notes predominate for the SP, accounting for $85 \%$ of the total number of materials published in the analyzed media outlet. Information genres in general make up almost $90 \%$ of the analyzed number. Notes were published on behalf of the site ("Osvita.ua") on the rights of rewrite. A paywall is absent, native advertising is largely present, a newsletter is absent, the mobile version has imperfect navigation.

In February 2020 we recorded three news about the possible impact of the spread of COVID-19 on the organization of the educational process at different levels, in March (Ukraine recorded the first case of infection) we already had comments from officials and brief reports on the educational process in countries that have already experienced restrictions caused by COVID-19. The number of news increased sharply in April-May, which corresponded to the general news agenda and the beginning of the introduction of national quarantine. The number of news on this topic decreased slightly in June, and increased again in August due to the organization of the introductory campaign and the beginning of the school year under the conditions of restrictions and zonal division.

Analysis of the sources of content for the SP on the site "Osvita.ua" showed that only $37 \%$ of the content was unique. A majority of the materials were borrowed from the website of the MESU (40\%).

\section{2. "Pedpresa"}

During the quantitative content analysis of the online media outlet "Pedagogical Press", we analyzed 761 materials of various genres, posted on the website of "Pedpresa" for the period from August 30, 2019 to August 30, 2020. Notes amounted to 719 (94.5\%), articles - 29 (3.8\%) reports - 0, inter- views - $13(1.7 \%)$. Both author's and materials linking to official sources (UCEQA, MESU, other sites) were taken into account. Most materials were related to "primary and secondary education" (34.4\%), "higher education" (29.8\%), the least - "science" (11\%), "vocational education" (10.3\%).

Figure 3 indicates the results of content analysis for the SP of the content of the online educational media outlet "Pedpresa" in the context of the number of included materials in accordance with the analyzed fields of education.

Figure 3: The amount of materials in the "Pedresa" for the SP in accordance with the analyzed fields of education.

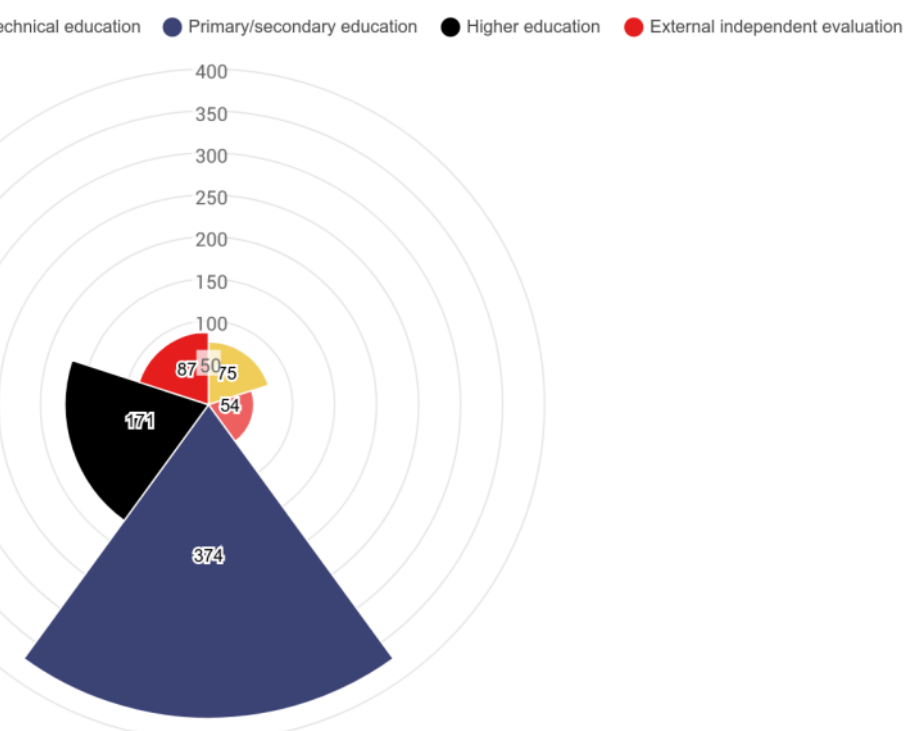

Source: content analysis data for the SP.

A paywall is absent, native advertising is present in small quantities, a newsletter is absent, the mobile version has convenient navigation - the version for the mobile device is developed.

Starting from 1.02.20 on the website "Pedpresa" we recorded an average of several weekly news regarding the organization of the educational process under epidemic conditions. The amount of news rose sharply in April, decreased slightly in July, and rose again in late August. It is worth noting that in August, "Pedpresa" had a two-week break and materials on the site rarely appeared.

Analysis of the sources of origin of the material showed that only $17 \%$ of the content was unique, the vast majority was borrowed from the Ministry of Education and Science, UCEQA and other sources (including Russian and European ones). This can be explained in some way by the fact that the direct owner of "Pedpresa" is the Ministry of Education and Science of Ukraine, but there may be other factors, such as an insufficient number of staff, which, as a result, reduces the percentage of copyrighted content or, as a reason for the previous point, insufficient funding. A possible precondition is the involvement of journalists in the preparation of pedagogical newspapers and magazines of the publishing 
house "Pedpresa", thus there is a "scattering" of the staff. This reason was mentioned in a conversation by an anonymous source from "Pedpresa" (one of the editors). According to the source, the owners are more interested in "mass earnings from specialized publications and their advertising among educational institutions" than in the creation of quality information and analytical resources that do not bring such profits.

In general, on the online media websites of "Osvita.ua" and "Pedpresa" the percentage distribution by education fields was as follows: "preschool education" - $16.20 \%$, "primary and secondary education" $33.80 \%$, "vocational education" - $9.60 \%$, "higher education" - $29.30 \%$, "science" - $9.70 \%$ and "andropedagogy" - $1.40 \%$.

\section{3. "NUS" and "Osvitoria"}

The New Ukrainian School is an online media outlet created with the support of the Ministry of Education and Science of Ukraine for the purpose of "communication within the framework of the educational reform of the New Ukrainian School." This is a so-called young player in the educational media market. "Osvitoria" is an online media outlet of the non-profit public association of the same name.

These media are actively working on the principles of content marketing using various media channels, namely "content engagement" (see Gallego, 2016, p. 220). There are interactive maps, infographics, tests, practices of informing interaction on "Osvitoria"; as for "NUS", it carries out creative distribution of news to subscribers, "Osvitoria" publishes listicles. A listicle as a "new media phenomenon" is "a genre of information and entertainment journalism", which uses a numbered list for the composition, which makes it possible to "split" the information into consecutive parts for better perception. Researcher Okrent believes that the listicle facilitates perception, "differentiating information", and provides the possibility to structure the idea, as does the "haiku or limerick" (Okrent, 2014).

There are the following examples of listicles: "10 best educational videos of the year" from "Osvitoria", "Merry Christmas shelf: 10 children's books for the winter holidays". Researcher Sadri from the University of Alabama conducted a questionnaire among millennials. Respondents were proposed to read the article in one of the formats - traditional or in the form of a list. The study found that respondents rated the listicle as more plausible (Sadri, 2019, p. 83-98).

Figure 4 shows the number of materials in the "Osvitoria" for the SP according to the analyzed fields of education. Articles make up $23.2 \%$.

"NUS" is designed to inform the audience about news related to the educational reform of the New Ukrainian School. In addition, the site contains a lot of content on international experience, as well as a significant amount of material on working with children with special educational needs. Key sections - "News", "Articles", "Poster", "There are questions', “Lessons. COVID-19”, “Inclusion”, "Learning together". This is a typical example of a mutated educational media outlet (mixing news and didactic content). The number of materials found for the SP is 418. More than $70 \%$ of the materials are unique. A paywall is absent, native advertising is largely present, a newsletter is present, the mobile version has good navigation.

Figure 4: The amount of materials in the "Osvitoria" for the SP in accordance with the analyzed fields of education.

primary education inclusion

educational funding distance learning education abroad 300

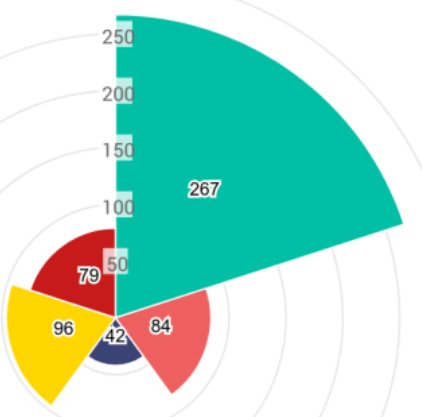

Source: content analysis data for the SP.

Figure 5 shows the number of materials in "NUS" for the SP according to the analyzed fields of education. Articles make up $29.4 \%$.

Figure 5: The number of materials in the "NUS" for the SP in accordance with the analyzed fields of education.

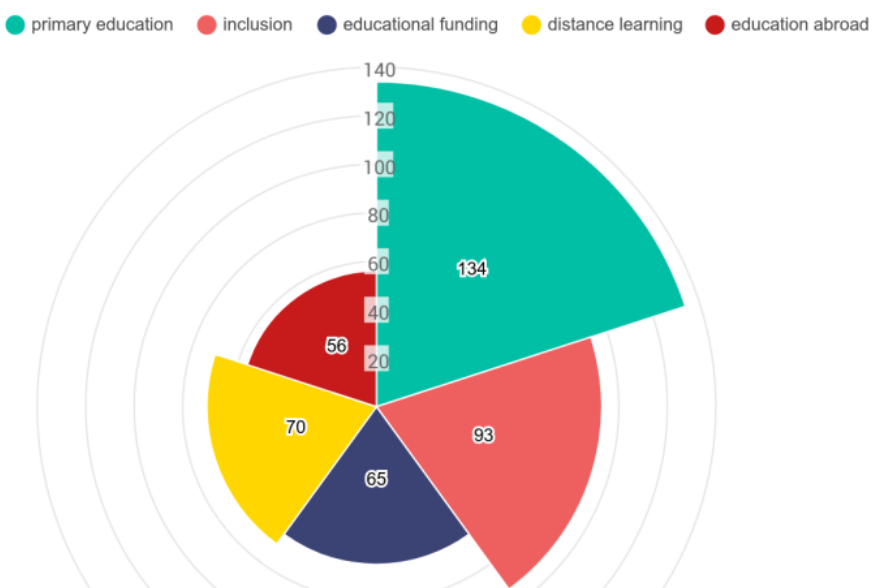

Source: content analysis data for the SP. 
In the process of analysis, we found that both "Osvitoria" and "NUS" use storytelling techniques, filling the site with visual content. Among the main advantages of "Osvitoria" are multimedia stories, through which the reader dives into the essence of what is said, takes interest in the continuation, as well as the use of listicles and attraction to the cultural and mythological segment. Among the disadvantages are a lack of variety in topics, reducing the role of information. Among the advantages of "NUS" are the uniqueness of the platform as a product of educational reform, where mind ideas are explicated and meanings are generated, and the interest in readers' opinions - interaction and contact with the audience. As for the disadvantages - the generation of official opinions with a low share of criticism.

\section{Conclusions and discussion}

Among the analyzed content of four online educational editions ( 3352 publications) it was found that the genre structure was dominated by notes $(2714$; $80.9 \%)$, there was a lack of reports $(56 ; 1.7 \%)$ and interviews (130; 3,9\%).

There is a problem with unique content. Most of the materials of "Pedpresa" (83\%), as well as a significant part of "Osvita.ua" (63\%) are borrowed or supplemented material obtained from the sites of the MESU, UCEQA or other sources.

The number of materials related to the forms and processes of distance education is relatively high. The growth of these materials is related to the measures taken by the Government of Ukraine in the framework of the fight against the COVID-19 pandemic.

Some media outlets have a low amount of materials related to the education of children with special educational needs ("Pedpresa", "Osvita.ua"), as well as processes taking place in Ukrainian science (all analyzed media outlets).

Among the materials regarding the field of preschool education, the topics of distance education, organization of education in schools under quarantine conditions and problem of establishing the child's personal space prevail. "Osvitoria" and "NUS" are the most informed about this topic, and the least informed is "Pedpresa". The topics of continuity between preschool and primary education, inclusion in secondary schools were poorly covered. Among the materials related to the field of primary and secondary education, the topics of distance learning, the new Ukrainian school, external evaluation and teachers' salaries prevail, oligophrenic, deaf and blindness topics, students' achievements at international competitions are poorly covered. When talking about vocational education, all topics are poorly covered too. "Pedpresa" (7\% of the total number of materials) and "Osvita.ua" (almost 5\%) write the most about this field.

Regarding the above-mentioned information, it will be expedient to increase the interest of Ukrainian media in the problems of science, increase the amount of materials on educational practices in vo- cational education institutions and the amount of author's content, including articles, as well as reports from educational institutions and interviews by successful managers and young people.

It is worthwhile to:

1. Increase the interest of the Ukrainian media in the problems of science and education of children with special educational needs,

2. Expand the number of materials on successful educational practices in vocational education institutions,

3. Increase the amount of author's content, reports from educational institutions, success stories,

4. Use storytelling techniques, attract multimedia tools to work with content,

5. Improve collaboration with the audience, allow readers to choose interesting topics and suggest stories.

\section{Abbreviations used in the research}

MESU - Ministry of Education and Science of Ukraine.

CS MESU - Communication strategy of the Ministry of Education and Science of Ukraine.

NUS - The New Ukrainian School.

UCEQA - Ukrainian Center for Educational Quality Assessment.

EIT - External independent evaluation.

\section{References (translated and transliterated)}

Anderson, G. L. (2007). Media's impact on educational policies and practices: Political spectacle and social control. Peabody Journal of Education, 82(1), 103-120. https://doi.org/ $10.1080 / 01619560709336538$

Cohen, H. (2012, October 19). 11 Fundamental skills your content creation team needs. https://heidicohen.com/11-fundamentalskills-your-content-creation-team-needs

CS MESU (2017). Komunikacijna strategija MONU 2017-2020 [Communication Strategy of the Ministry of Education and Science of Ukraine 2017-2020]. https://mon.gov.ua/storage/ app/media/komunikaczijna-strategiya-mon-2017-2020.pdf

CS MESU (2019). Komunikacijna strategija MONU 2019-2021 [Communication Strategy of the Ministry of Education and Science of Ukraine 2019-2021]. https://mon.gov.ua/storage/ app/media/media/MOES\%20Com\%20strategy\%2020192022.pdf

Detector Media (2008, June 4). Sim orijentyriv "TSN": Skandaly, Sensacii', Strah, Smert', Seks, Smih i Groshi [The Seven Benchmarks of TSN: Scandals, Sensations, Fear, Death, Sex, Laughter and Money]. https://detectormedia/ production/article/38798/2008-06-04-sim-oriientyriv-tsnskandaly-sensatsii-strakh-smert-seks-smikh-i-groshi

Dryzytska, N. (2019, December 11). Influence Marketing \& Media: chomu infliuensery (ne)potribni ZMI [Influence Marketing \& Media: Why Influencers (don't) need media]. https://www.thelede.media/istorii/2019/12/11/472

Gallego, J. P. (2016). Metodología y contenido axiológico de los programas de educación en valores. Foro de Educación, 21, 217-226. http://doi.org/10.14516/fde.2016.014.021.011

García, M. B. (2017). Funciones de las herramientas multimedia interactivas para la enseñanza en educación preescolar. Praxis, 13(1), 17-24. https://doi.org/10.21676/23897856.2063

García, M. (2014, January 30). The media quintet? Retrieved from: https://garciamedia.com/blog/the_media_quintet/

Haas, E. (2007). False equivalency: Think tank references on education in the news media. Peabody Journal of Education, 82(1), 63102. https://doi.org/10.1080/01619560709336537

Hansen, D. T. (2002). Dewey's conception of an environment for teaching and learning. Curriculum Inquiry, 32(3), 267-280. https://doi.org/10.1111/1467-873X.00228

Karpenko, M. (2015, July 15). Osvita protiahom zhyttia yak chynnyk liudskoho rozvytku [Lifelong learning as a factor in 
human development]. https://niss.gov.ua/doslidzhennya/ gumanitarniy-rozvitok/osvita-protyagom-zhittya-yakchinnik-lyudskogo-rozvitku

Katerynych, P. (2020). Educational journalism in Ukraine: current status and development prospects. Synopsis: text, context, media, 26(4), 151-158. https://doi.org/10.28925/2311-259x.2020.4.6

Kefela, G. T. (2010). Knowledge-based economy and society has become a vital commodity to countries. International NGO Journal, 5(7), 160-166. https://doi.org/10.5897/ING0J.9000069

Killeen, K. (2007). How the media misleads the story of school consumerism: A perspective from school finance. Peabody Journal of Education, 82(1), 32-62. https://doi.org/10.1080/ 01619560709336536

Lemos, M. H. (2017). Comment on Laurence Claus, The Divided Executive. Duke J. Const. L. \& Pub. Pol'y, 13, 51. https://scholarship.law.duke.edu/cgi/viewcontent.cgi?article $=1144 \&$ context $=$ djclpp

Manic, M. (2015). The Rise of native advertising. Bulletin of the Transilvania University of Brasov. Economic Sciences, $V$, 8(1), 53.

Miller, R. A., \& Albert, K. (2015). If it leads, it bleeds (and if it bleeds, it leads): Media coverage and fatalities in militarized interstate disputes. Political Communication, 32(1), 61-82. https://doi.org/10.1080/10584609.2014.880976

Moses, M. S. (2007). The media as educators, educational research, and autonomous deliberation. Peabody Journal of Education, 82(1), 150-165. https://doi.org/10.1080/01619560709336540

Nacos, B. (2016). Mass-mediated terrorism: Mainstream and digital media in terrorism and counterterrorism. Rowman \& Littlefield. https://doi.org/10.4324/9781315641270

Okrent, A. (2014, January). The listicle as literary form. Uchicago Magazine. https://mag.uchicago.edu/arts-humanities/listicleliterary-form

Opfer, V. D. (2007). Developing a research agenda on the media and education. Peabody Journal of Education, 82(1), 166-177. https://doi.org/10.1080/01619560709336541

Pérez, G. (1998). El periodismo educativo: objetivos. Ámbitos Revista Internacional de Comunicación, 15, 172-183. https://www.researchgate.net/publication/26527454_El_per iodismo_educativo_objetivos

Petrushenko, 0. (2016). Poniattia "suspilstvo znan", yoho analiz ta otsinka [The concept of "knowledge society," its analysis and evaluation]. Humanitarian Vision, 2, 105-109. https://doi.org/10.23939/shv2016.02.105

Preeti (2014). Education and Role of Media in Education System. International Journal of Scientific Engineering and Research, 2, 3, 174. https://www.ijser.in/archives/v2i3/SjIwMTMxNTg=.pdf

Sadri, S. R. (2019). Listicles and the modern news article: comparing the perceived credibility of listicles and traditional articles among millennial media consumers. Atlantic Journal of Communication, 27(2), 83-98. https://doi.org/10.1080/ 15456870.2019 .1574794
Savinova, O. N. (2008). Transformacija mediasistemy v sovremennyh uslovijah: $\mathrm{k}$ voprosu aberracii funkcij SMI [Transformation of the media system in modern conditions: aberration of media functions]. Vestnik Nizhegorodskogo universiteta im. N. I. Lobachevskogo, 1. https://cyberleninka.ru/ article/n/transformatsiya-mediasistemy-v-sovremennyhusloviyah-k-voprosu-aberratsii-funktsiy-smi

Sjøvaag, H. (2016). Introducing the Paywall: A case study of content changes in three online newspapers. Journalism Practice, 10(3), 304-322. https://doi.org/10.1080/ 17512786.2015.1017595

Subetto, A. I. (2013). Obrazovatel'noe obshhestvo i realizacija strategii razvitija obrazovanija v XXI veke chast' 4 [The educational society and the implementation of the strategy for educational development in the twentieth century part 4]. Astrahanskij vestnik jekologicheskogo obrazovanija, 2(24). https://cyberleninka.ru/article/n/obrazovatelnoe-obschestvo-irealizatsiya-strategii-razvitiya-obrazovaniya-v-xxi-veke-chast-4

Talanchuk, P. (2014, December 10). Navchannia protiahom zhyttia sertsevyna suchasnoho osvitnoho protsesu [Lifelong learning is at the heart of the modern educational process]. [accessed 20 January 2021]. http://vnz.org.ua/statti/7038-navchannjaprotjagom-zhyttja-sertsevyna-suchasnogo-osvitnogo-protsesupetro-talanchuk

Tillman, L. C., \& Trier, J. (2007). Boston Public as public pedagogy: Implications for teacher preparation and school leadership. Peabody Journal of Education, 82(1), 121-149. https://doi.org/10.1080/01619560709336539

Ukrainska Pravda (2020, March 3). V Ukraini - pershyi vypadok koronavirusu [The first case of coronavirus in Ukraine]. https://www.pravda.com.ua/news/2020/03/3/7242332/

UNESCO. Institute for lifelong learning. https://uil.unesco.org/

Wain, K. (2016). Philosophy of lifelong education. Routledge. https://doi.org/10.4324/9781315531090

Wallace, M. (2007). Educational myth-making with due accuracy and impartiality. Peabody Journal of Education, 82, 1, 10-31. https://doi.org/10.1080/01619560709336535

Wenger, D. H., \& Potter, D. (2018). Advancing the Story: Quality Journalism in a Digital World. CQ Press.

Wimmer, R. D., \& Dominick, J. R. (2013). Mass media research. Cengage learning.

YourDictionary. Newsmaker. https://www.yourdictionary.com/ newsmaker/

Zhilavskaja, I. V. (2008). Optimizacija vzaimodejstvija SMI i molodezhnoj auditorii na osnove mediaobrazovatel'nyh strategij $i$ tehnologij [Optimization of interaction between mass media and youth audience on the basis of media-educational strategies and technologies]. (Doctoral dissertation, Moskovskij gosudarstvennyj universitet im. M. V. Lomonosova (MGU). Fakul'tet zhurnalistiki). https://www.dissercat.com/ content/optimizatsiya-vzaimodeistviya-smi-i-molodezhnoiauditorii-na-osnove-mediaobrazovatelnykh-str

\title{
ОСВІТНЯ ЖУРНАЛІСТИКА В УКРАЇНІ (РЕЗУЛЬТАТИ КОНТЕНТ-АНАЛІЗУ)
}

\author{
Петро Катеринич \\ Київський національний університет імені Тараса Шевченка, Україна
}

У статті описано теоретичні підходи до розуміння освітньої журналістики, схарактеризовано поняття освітньої журналістики в українському та світовому медіапросторі, побудовано модель впливу сторонніх факторів на висвітлення питань освіти у 3МІ. Мета дослідження - 1) вивчення теоретичних розробок та підходів до функціонування освітньої журналістики в медіа середовищі; 2) простежити жанрові та тематичні особливості аналізованих освітніх ЗМІ (на прикладі «Педпреса», «Освіта.иа», «НУШ», «Освіторія»). Методом дослідження $є$ контент-аналіз спеціалізованих ЗМІ освітньої тематики. Ці ЗМІ мають регулярне наповнення різножанровим і різнотематичним контентом освітньої тематики, активно застосовують інструменти для створення мультимедійного контенту, мають найвищий трафік в сегменті інтернет-ЗМІ освітнього профілю (за даними сервісу 
статистики «Similar Web». Серед проаналізованого контенту чотирьох інтернет-видань освітньої спеціалізації (3352 публікації) встановлено, що за жанровою структурою превалюють замітки (2714; 80,9\%), відчувається брак репортажів $(56 ; 1,7 \%)$ та інтерв'ю (130; 3,9\%). Слабка присутність аналітичних жанрів особливо відчутна стосовно тем дошкільної, інклюзивної та професійно-технічної освіти. Контент-аналіз матеріалів групи 1 (2366 матеріалів, 70,6\% від усієї вибірки у двох групах) показав, що найбільша кількість матеріалів за аналізований період стосувалася тем початкової та середньої освіти (1131 матеріал, 47,8\%), найменша - професійно-технічної освіти (131, 5,5\%). Аналіз матеріалів у другій групі (29,4\% від аналізованих матеріалів в обох групах) показав, що превалює тема початкової освіти (401 матеріал, 40,7\%), значною є доля матеріалів, що стосуються дистанційної освіти (16,7\% у «НУШ» та 16,9\% в «Освіторії»). Більшість матеріалів «Педпреси» (83\%), а також значна частина «Освіти.иа» (63\%) є запозиченням або доповненим матеріалом, отриманим із сайтів МОНУ, УЦОЯо чи інших джерел. Ці результати становлять практичне значення дослідження.

Ключові слова: освітня журналістика; освітній журналіст; 3MI; контент-аналіз; освітня журналістика в Україні. 